\title{
Quercivorol as a lure for the polyphagous and Kuroshio shot hole borers, Euwallacea spp. nr. fornicatus (Coleoptera: Scolytinae), vectors of Fusarium dieback
}

Christine Dodge ${ }^{\text {Corresp.., }}{ }^{1}$, Jessica Coolidge ${ }^{1}$, Miriam Cooperband ${ }^{2}$, Allard Cossé ${ }^{2}$, Daniel Carrillo ${ }^{3}$, Richard Stouthamer ${ }^{1}$

1 Department of Entomology, University of California, Riverside, Riverside, California, United States

2 Otis Laboratory, USDA-APHIS, Buzzards Bay, Massachusetts, United States

${ }^{3}$ Tropical Research and Education Center, University of Florida, Homestead, Florida, United States

Corresponding Author: Christine Dodge

Email address: christine.dodge@email.ucr.edu

The polyphagous shot hole borer and Kuroshio shot hole borer, two members of the Euwallacea fornicatus species complex (Coleoptera: Curculionidae: Scolytinae), are invasive ambrosia beetles that harbor distinct species of Fusarium fungal symbionts. Together with the damage caused by gallery construction, these two phytopathogenic Fusarium species are responsible for the emerging tree disease Fusarium dieback, which affects over 50 common tree species in Southern California. Host trees suffer branch dieback as the xylem is blocked by invading beetles and fungi, forcing the costly removal of dead and dying trees in urban areas. The beetles are also threatening natural riparian habitats, and avocado is susceptible to Fusarium dieback as well, resulting in damage to the avocado industries in California and Israel. Currently there are no adequate control mechanisms for shot hole borers. This paper summarizes efforts to find a suitable lure to monitor shot hole borer invasions and dispersal. Field trials were conducted in two counties in Southern California over a span of two years. We find that the chemical quercivorol is highly attractive to these beetles, and perform subsequent field experiments attempting to optimize this lure. We also explore other methods of increasing trap catch and effects of other potential attractants, as well as the deterrents verbenone and piperitone. 
1 Quercivorol as a lure for the polyphagous and Kuroshio shot hole borers, Euwallacea

2 spp. nr. fornicatus (Coleoptera: Scolytinae), vectors of Fusarium dieback

3

4 Christine Dodge $^{1}$, Jessica Coolidge ${ }^{1}$, Miriam Cooperband ${ }^{2}$, Allard Cossé ${ }^{2}$, Daniel Carrillo ${ }^{3}$,

5 Richard Stouthamer ${ }^{1}$

6

7 1Department of Entomology, University of California, Riverside, CA 92521, USA

8 20tis Laboratory, USDA-APHIS, 1398 W. Truck Rd., Buzzards Bay, MA 02542, USA

$9{ }^{3}$ University of Florida, Tropical Research and Education Center, 18905 SW 280 ST, Homestead,

10 FL 33031, USA

11

12 Corresponding Author:

13 Christine Dodge ${ }^{1}$

14 Email address: christine.dodge@email.ucr.edu 
16 The polyphagous shot hole borer and Kuroshio shot hole borer, two members of the Euwallacea

17 fornicatus species complex (Coleoptera: Curculionidae: Scolytinae), are invasive ambrosia

18 beetles that harbor distinct species of Fusarium fungal symbionts. Together with the damage

19 caused by gallery construction, these two phytopathogenic Fusarium species are responsible for

20 the emerging tree disease Fusarium dieback, which affects over 50 common tree species in

21 Southern California. Host trees suffer branch dieback as the xylem is blocked by invading

22 beetles and fungi, forcing the costly removal of dead and dying trees in urban areas. The beetles

23 are also threatening natural riparian habitats, and avocado is susceptible to Fusarium dieback as

24 well, resulting in damage to the avocado industries in California and Israel. Currently there are

25 no adequate control mechanisms for shot hole borers. This paper summarizes efforts to find a

26 suitable lure to monitor shot hole borer invasions and dispersal. Field trials were conducted in

27 two counties in Southern California over a span of two years. We find that the chemical

28 quercivorol is highly attractive to these beetles, and perform subsequent field experiments

29 attempting to optimize this lure. We also explore other methods of increasing trap catch and

30 effects of other potential attractants, as well as the deterrents verbenone and piperitone. 


\section{Introduction}

32

Fusarium dieback is an emerging plant disease, first reported in Israel in 2009 (Mendel et al. 2012) and in Southern California in 2012 (Eskalen et al. 2012). The disease is caused in part

34

by two plant pathogenic fungi in the genus Fusarium (Ascomycota: Hypocreales), each of which is associated with an ambrosia beetle in the cryptic Euwallacea fornicatus species complex (Coleoptera: Curculionidae: Scolytinae) (Cooperband et al. 2016; Kasson et al. 2013; O'Donnell et al. 2015; Stouthamer et al. 2017). This species complex consists of at least three, and possibly five, morphologically indistinguishable ambrosia beetles from Southeast Asia (Stouthamer et al. 2017). Three members of this complex have invaded the United States: two in Southern California, and one in Florida and Hawaii. Until recently all members were thought to be the tea shot hole borer (TSHB) Euwallacea fornicatus Eichhoff (1868), a serious pest of tea in Sri Lanka (Austin 1956; Walgama \& Pallemulla 2005). Although morphologically indistinguishable, molecular analyses revealed significant divergence in mitochondrial and nuclear genes of all three beetles (Eskalen et al. 2013; Stouthamer et al. 2017), which were subsequently given different common names to distinguish them. The beetle clade invading Florida and Hawaii is thought to be Euwallacea fornicatus sensu stricto, and so is referred to here as the TSHB (Stouthamer et al. 2017). Two distinct invasions occurred in Southern California: the beetles invading the Los Angeles and San Diego areas have been given the common names polyphagous shot hole borer (PSHB; Cooperband et al. 2016; Eskalen et al. 2013), and Kuroshio shot hole borer (KSHB; Stouthamer et al. 2017), respectively. All Fusarium species associated with these shot hole borers (SHB) are members of the Ambrosia Fusarium Clade in the Fusarium solani species complex, which includes a number of phytopathogens as well as opportunistic pathogens of mammals (Kasson et al. 2013; O'Donnell et al. 2008). 
55 Xyleborini, a large ( 1300 spp.) tribe consisting solely of haplodiploid inbreeding species

56 (Normark et al. 1999). Members of this tribe form obligate mutualisms with specific ambrosia

57 fungi, which they cultivate and feed upon. Ambrosia beetles transport and introduce the fungi to

58 new host trees in the process of boring brood galleries for reproduction. Unlike most ambrosia

59 beetles, which colonize dead or dying trees (Raffa et al. 1993), PSHB and KSHB attack living,

60 healthy trees, many of which are susceptible to Fusarium dieback. As the Fusarium invades the

61 host tree vascular system, it gradually restricts the flow of water and nutrients (Eskalen et al.

62 2012). Paired with structural damage caused by beetle gallery formation, this causes branch

63 dieback, from which trees are unable to recover (Eskalen et al. 2012; Mendel et al. 2012).

64 The PSHB (Euwallacea sp. \#1 in O'Donnell et al. 2015) harbors one of the causative

65 agents of Fusarium dieback, Fusarium euwallaceae (Freeman et al. 2013b; AF-2 in O'Donnell et

66 al. 2015). The KSHB (Euwallacea sp. \#5 in O'Donnell et al. 2015) vectors the other causative

67 agent, an unnamed Fusarium sp. (AF-12 in O'Donnell et al., 2015). Both SHB also harbor

68 additional fungal symbionts: the PSHB carries Graphium euwallaceae and Paracremonium

69 pembeum (Lynch et al. 2016), and KSHB carries an undescribed Graphium species. It was

70 shown that PSHB can complete their development on F. euwallaceae, but not on other Fusarium

71 species (Freeman et al. 2013a). Additionally, PSHB can complete their development when raised

72 solely on G. euwallaceae as well as on F. euwallaceae (Freeman et al. 2015), which is

73 considered to be the primary symbiont. Similarly, we have observed KSHB completing their

74 development on their Fusarium symbiont, and experiments are ongoing to determine if they can

75 feed and reproduce on their Graphium associate (unpublished data). The role of Paracremonium

76 pembeum is unknown, and has not been found in association with natural populations of KSHB. 

extremely female-biased sex ratios (Kirkendall 1993). Female SHB disperse already mated and carrying Fusarium spores in mandibular mycangia to inoculate brood galleries of their own. However, mating pre-dispersal is not a requirement for female SHB since laying an unfertilized egg will produce a son, which she can mate with to produce diploid daughters (Cooperband et al. 2016). Combined, these ecological strategies enable SHB to rapidly colonize new areas (Kirkendall \& Jordal 2006), and the habit of culturing and feeding on fungi rather than directly on plant material allows them to occupy a wide range of hosts (Jordal 2000).

Although symptoms of Fusarium dieback were recognized much later, the PSHB was 2006). Reports of the KSHB in San Diego County began more recently in 2012 (Eskalen et al. 2012). Since their respective invasions, the PSHB and KSHB together have spread across six counties in California and are also found in adjacent areas of Mexico (García-Avila et al. 2016; for current distributions in California, see http://eskalenlab.ucr.edu/distribution.html). The heart of the PSHB infestation spans Los Angeles and Orange Counties, although they have ranged into neighboring counties as well. KSHB are mostly restricted to San Diego County and northern Mexico, but several specimens have been collected in other California counties farther north (Santa Barbara and San Luis Obispo Counties).

Over 50 tree species common to Southern California are susceptible to Fusarium dieback,

96 including a variety of urban, riparian, and agricultural hosts (Boland 2016; Cooperband et al.

97 2016; Eskalen et al. 2013). The most notable agricultural host is avocado, which has been

98 threatened by the presence of KSHB in San Diego County and PSHB in Ventura County.

99 California produces 90 percent of domestic avocados, about 70 percent of which are grown in 
100 these two counties (40 percent in San Diego, 30 percent in Ventura; California Avocado

101 Commission 2017). In the 2015-2016 season, avocados comprised a \$412 million industry in

102 California (California Avocado Commission 2017), the third highest crop value in the history of

103 California avocado production. Since the appearance of Fusarium dieback, the avocado

104 industries of Israel and California have faced losses from damage (Freeman et al. 2013b; Mendel

105 et al. 2012) and although the risk seems to be decreasing, the SHB and phytopathogenic

106 Fusarium species continue to pose a threat. The beetle-fungus complex has also caused

107 substantial losses in urban environments, where forced removal of thousands of infested

108 landscape trees has cost millions of dollars over the past few years (University of California

109 2015). Additionally, the beetle-fungus complex is invading natural habitats and threatening

110 native plant species. Over a period of six months, disturbance from KSHB resulted in mortality

111 of the majority of native willows in the Tijuana River Valley in San Diego County (Boland

112 2016). Willows were the dominant tree species in this riparian habitat that supports numerous

113 plant and animal species, some of which are endangered (Boland 2016). The spread of SHB and

114 their phytopathogenic fungi therefore have the potential to cause tremendous economic and

115 environmental losses in urban, agricultural, and natural habitats.

116 Previously there has been no reliable method of trapping SHB to monitor their

117 distribution and spread. Until recently, the only means of confirming their presence in an area

118 was to find specimens randomly in unbaited Lindgren traps. Here we present the results of

119 eleven field experiments spanning two years, in which we discover and optimize an effective

120 lure for the polyphagous and Kuroshio SHB: the semiochemical quercivorol. We also report

121 other methods of increasing SHB trap catch through trap modifications, as well as the effects of 
122 other potential lures. Finally, we test the effects of chemical deterrents on SHB to determine if

123 and to what extent we can repel them in the field.

124

125

\section{Methods}

126

Quercivorol. In a field study to screen various semiochemicals for attraction, Synergy

127 Semiochemicals Corp. (Burnaby, BC, Canada) provided a quercivorol lure (Batch \#3250) paired

128 with an ultrahigh release (UHR) ethanol bag. Together they were found to attract the TSHB

129 Euwallacea fornicatus in Florida (Carrillo et al. 2015). Due to their close evolutionary

130 relationship to TSHB, we used this lure in an attempt to attract PSHB and KSHB in California.

131 Quercivorol has also recently been used to capture PSHB in Israel (Byers et al. 2017).

132 Quercivorol was first identified from volatiles found in the boring frass of the oak

133 ambrosia beetle Platypus quercivorus (Tokoro et al. 2007), for which it has been identified as an

134 aggregation pheromone (Kashiwagi et al. 2006). It has also been found in odors from artificial

135 diet (made with boxelder sawdust) infested with the associated symbiont of PSHB, $F$.

136 euwallacea (Cooperband and Cossé, pers. comm.). Quercivorol ((1S,4R)-p-menth-2-en-1-ol )

137 has two chiral centers (Kashiwagi et al. 2006; Tokoro et al. 2007) and p-menth-2-en-1-ol can

138 have four possible enantiomers. SHB may show varying levels of attraction to these different

139 structural isomers, as has been seen in other scolytines (Byers 1989; Byers et al. 2017).

140 Experimental Design. Experiments were performed in avocado groves in two locations

141 in Southern California: La Habra Heights, Los Angeles County (33 $\left.57^{\prime} 33^{\prime \prime N}, 117^{\circ} 58^{\prime} 10^{\prime \prime} \mathrm{W}\right)$ and

142 Escondido, San Diego County $\left(33^{\circ} 08^{\prime} 53^{\prime \prime} \mathrm{N}, 117^{\circ} 01^{\prime} 19^{\prime \prime} \mathrm{W}\right)$. Due to their distinct geographical

143 ranges, experiments performed in La Habra Heights targeted PSHB, while experiments 
144 performed in Escondido targeted KSHB. Experiments were performed sequentially between the 145 summers of 2014 and 2016.

146 Black 12-funnel Lindgren traps were used for all experiments and were hung from

147 vertical metal poles 2.5 meters in height. Poles were bent to a right angle at the top, and traps

148 were secured to the end of the pole so that they hung freely. To prevent poles from being top

149 heavy, 1-meter strips of rebar were hammered into the ground first, and the poles were placed

150 over the rebar to secure them. Traps were spaced roughly 20 meters apart and arranged into

151 randomized complete blocks to control for field location. Whenever trap contents were collected,

152 lures were rotated throughout the block to avoid effects of location bias over the course of the

153 experiment. Lures were attached to the second lowest funnel of Lindgren traps. Cups were half-

154 filled with propylene glycol antifreeze to collect, euthanize, and preserve specimens (Allison \&

155 Redak 2017), which were collected weekly or twice weekly for analysis.

156 Experiment 1: Testing Fungal Odors. Previous studies have shown certain ambrosia

157 beetles to be attracted to the scent of their fungal symbionts (Hulcr et al. 2011; Kuhns et al.

158 2014). Two novel lures were tested for PSHB attraction: 1) a mixture of their symbiotic fungi $F$.

159 euwallaceae and G. euwallaceae, grown on an artificial sawdust-based diet medium (modified

160 from Peer \& Taborsky 2004); and 2) a chemical lure consisting of a quercivorol bubble cap

161 (Synergy Semiochemicals, Batch \#3250) and UHR ethanol lure. The diet medium was prepared

162 with sawdust from box elder, a reproductive host of SHB. $25 \mathrm{ml}$ of autoclaved medium was

163 poured into a 50ml plastic Falcon tube and allowed to solidify. Separate, equally concentrated

164 spore suspensions of $F$. euwallaceae and G. euwallaceae were prepared by the Eskalen lab in the

165 Department of Plant Pathology at the University of California, Riverside, and then combined.

$1662 \mathrm{ml}$ of the resulting mixture was used to inoculate diet tubes, which were incubated at room 
167 temperature $\left(\sim 24^{\circ} \mathrm{C}\right)$ for one week before use in Experiment 1 . This allowed the fungi enough

168 time to grow over the surface of the diet. The entire fungal-diet mass was removed from each

169 tube in the field and attached to traps using a mesh pocket, to allow fungal scents to escape.

170 Uninoculated diet tubes were prepared and used as a control for SHB attraction to host volatiles

171 in the sawdust. Blank traps served as a negative control. This experiment took place in La Habra

172 Heights for four weeks from Aug-Sept $2014(\mathrm{~N}=28$, seven replicates of four treatments). Trap

173 contents were collected weekly. Because the exposed artificial diet plugs dry out in the field,

174 fresh inoculated and uninoculated diet tubes were prepared weekly to replace old plugs.

175 Experiment 2: Effect of Ethanol on Quercivorol. After noting in a previous experiment

176 that PSHB were not attracted to ethanol lures (unpublished data), a study was done to determine

177 if the compound quercivorol performs better alone or if paired with the UHR ethanol lure.

178 Experimental traps were baited with a quercivorol bubble cap (Batch \#3250), or with a

179 quercivorol bubble cap and UHR ethanol lure. Blank traps served as a control. This experiment

180 was performed in La Habra Heights for six weeks from Sept-Oct $2014(\mathrm{~N}=45,15$ replicates of

181 three treatments). Trap contents were collected weekly for analysis.

182

Experiment 3: Analysis of Three Different Quercivorol Blends. Synergy

183 Semiochemicals Corp. provided lures containing two additional ratios of quercivorol and its

184 stereoisomers (trans $p$-menthenols) for us to test against the original (Batch \#3250). The lure

185 contents differed in ratios of different quercivorol enantiomers. Batch \#3250 contained $60 \%$

186 cis $/ 40 \%$ trans $p$-menthenols $($ load $=280 \mathrm{mg}$; release rate $=6 \mathrm{mg} /$ day $)$; Batch \#3039 contained

$18726.7 \%$ cis $/ 53.3 \%$ trans $p$-menthenols, $20 \%$ piperitols $($ load $=290 \mathrm{mg}$; release rate $=6.5 \mathrm{mg} / \mathrm{day})$;

188 and Batch \#3355 contained $11 \%$ cis $/ 87 \%$ trans $p$-menthenols (load $=280 \mathrm{mg}$; release rate $=$

189 7.9mg/day) (David Wakarchuk, Synergy Semiochemicals, pers. comm., 2016). This experiment 
190 was performed in October 2014 in Escondido for three weeks $(\mathrm{N}=30,10$ replicates of three

191 treatments). Trap contents were collected weekly.

192 Experiment 4: Analysis of Two Additional Quercivorol Blends. Two additional lures,

193 Batch \#3361 and Batch \#3362, were provided by Synergy Semiochemicals Corp. for comparison

194 to Batch \#3250. Batch \#3361 contained 85\% cis/15\% trans $p$-menthenols (load = 280mg; release 195 rate $=3 \mathrm{mg} /$ day $)$. Batch \#3362 contained $57 \%$ cis $/ 38 \%$ trans $p$-menthenols, $5 \%$ piperitols $($ load $=$ 196 280mg; release rate $=3 \mathrm{mg} /$ day) (David Wakarchuk, Synergy Semiochemicals, pers. comm., 197 2016). This experiment was performed in Escondido in March 2015 for two weeks $(\mathrm{N}=42,14$ 198 replicates of three treatments). Trap contents were collected twice weekly. Rica) provided quercivorol lures labeled as P548 (68\% cis/32\% trans $p$-menthenols, load =

201 200mg; Cossé, pers. comm.). We tested these against Synergy’s Batch \#3361 lure, to see if there 202 was any difference in their attractiveness to SHB. A blank trap served as a control. This 203 experiment took place in Escondido for two weeks from May-Jun 2015 (N = 30, 10 replicates of 204 three treatments). Trap contents were collected twice weekly. purchase, we switched to using ethanol-based antifreeze for our experiments. However, due to hot daytime temperatures and dry conditions in the field, evaporation of ethanol-based antifreeze used in the trap cups resulted in poor morphological and molecular insect preservation. A solution containing dimethyl sulphoxide (DMSO), EDTA, and saturated $\mathrm{NaCl}$, abbreviated

210 DESS, was previously described for high-temperature preservation of DNA in a variety of 211 animals (Yoder et al. 2006). An experiment was performed to see if DESS solution would affect 212 the number of SHB collected from traps, in order to consider its utility as a preservation agent in 
213 the field. The trap cup treatments consisted of ethanol-based antifreeze, DESS solution, or an

214 empty (dry) cup. DESS solution was prepared at the University of California, Riverside and

215 transported to the field as a liquid. Trap cups were filled halfway for both the antifreeze and

216 DESS treatments. Two moistened, crumpled Kimwipes were placed in dry cups to dissuade

217 captured insects from flying away. A P548 lure was used for all treatments to attract SHB. This

218 experiment was performed in July 2015 in Escondido for two weeks $(\mathrm{N}=30,10$ replicates of

219 three treatments). Trap contents were collected twice weekly.

Experiment 7: Effect of Funnel Diameter and Cup Contents on SHB Capture. Due

221 to concerns that live beetles could escape the Lindgren trap cups through the hole of the lowest

222 funnel, an experiment was performed to determine if the size of the funnel hole had an effect on

223 the number of SHB collected. In "small" funnel treatments, a plastic funnel with a smaller hole

224 was glued to the rim of the trap cup to reduce the diameter through which trapped SHB could

225 escape. The effect of trap cup collection substrate was also tested. The treatments were as

226 follows: a) Lindgren funnel traps with no alterations, here called "large" funnel traps, with dry

227 cups; b) large funnel traps with cups containing DESS solution; and c) "small" funnel traps with

228 dry cups. A P548 lure was used for all treatments to attract SHB, and crumpled, moistened

229 Kimwipes were placed inside of dry cups. This experiment was performed in Escondido in July

2302015 for two weeks $(\mathrm{N}=30,10$ replicates of three treatments). Trap contents were collected

231 twice weekly.

232 Experiment 8: Effect of P548 Concentration. The concentration of a lure has been

233 shown in some systems to determine the level of attractiveness to a target insect, ranging from

234 attraction to repulsion (Erbilgin et al. 2003; Kovanci et al. 2006; Witzgall et al. 2008). We sought

235 to determine whether the concentration of P548 had an effect on level of SHB attraction. In this 
236 experiment, one, two, or six identical P548 lures were attached to a trap to determine the

237 attractiveness of different P548 concentrations to SHB. This experiment was performed in

238 Escondido for six weeks between July-Sept $2015(\mathrm{~N}=30,10$ replicates of three treatments).

239 Trap contents were collected twice weekly.

Experiment 9: Analysis of P548 Lures with Different Release Rates. Three P548 lures

241 with varying release rates as described by the company, ChemTica Internacional, were tested.

242 All lures had the same chemical composition and load (200mg). "P548 A" had the full release

243 rate; "P548 B" had a 50\% release rate from that of P548 A; and "P548 C" had a 25\% release rate

244 from that of P548 A (Cam Oehlschlager, ChemTica Internacional, pers. comm., 2016). This

245 experiment took place in Escondido for four weeks between Sept-Oct 2015 ( $N=30,10$

246 replicates of three treatments). Trap contents were collected twice weekly.

247

Experiment 10: Effect of the Repellent Verbenone. To see if we could repel SHB in

248 the field, ChemTica Internacional provided pouches of Beetleblock Verbenone, a bark and

249 ambrosia beetle repellent. Verbenone has been used in the past to successfully deter

250 economically important bark beetles in the genera Ips and Dendroctonus (Borden et al. 1991;

251 Fettig et al. 2009), and has more recently been utilized for ambrosia beetle pests (Burbano et al.

252 2012; Hughes et al. 2017; Jaramillo et al. 2013). We tested the effect of verbenone on SHB by

253 pairing the verbenone pouch with a quercivorol lure (Synergy Semiochemicals, Batch \#3361), to

254 determine if the repellent offset the attractiveness of quercivorol. For a positive control we used a

255 Batch \#3361 lure alone, and for a negative control a blank trap was used. This experiment was

256 performed in La Habra Heights for three weeks between Oct-Nov $2015(\mathrm{~N}=30,10$ replicates of

257 three treatments). Trap contents were collected weekly. 
259 verbenone against another repellent, piperitone (Synergy Semiochemicals) to determine which

260 deters SHB more effectively. Piperitone was tested because it is the ketone form of the attractant

261 quercivorol, similar to verbenone being the ketone form of the attractant verbenol. This

262 experiment was the first to use piperitone as a repellent against ambrosia beetles. Similar to

263 Experiment 10, both repellents were paired with a quercivorol lure (Synergy Semiochemicals,

264 Batch \#3361) and were tested against a Batch \#3361 lure as a positive control. This experiment

265 was performed in La Habra Heights and lasted for six weeks between Aug-Sept $2016(\mathrm{~N}=30,10$

266 replicates of three treatments). Trap contents were collected weekly.

267 Statistical Analysis. Data was collected for each experiment in the form of counts, and

268 were found in all cases to be Poisson overdispersed (Pearson dispersion statistic $>1.0$ ). Data

269 were analyzed using a negative binomial regression, using the glm.nb function in the MASS

270 package (Venables \& Ripley 2002) in R to employ a generalized linear model (GLM) under the

271 assumptions of a negative binomial distribution. The number of shot hole borers captured was

272 modeled by the effects of treatment, date, and block. Multiple comparisons were performed

273 using Tukey contrasts of least-squares means, using the lsmeans package (Lenth 2016). To

274 account for outliers, analyses were performed both before and after removing outliers from the

275 data set. Noteworthy effects of outliers are discussed. All analyses were performed using the R

276 free software v3.2.1 (R Core Team 2015). Results are reported as raw count data. Box plots for

277 each experiment show sample minimum and maximum (horizontal lines at the bottom and top of

278 each plot, respectively) as well as sample median (heavy line inside of box). Upper and lower

279 quartiles are represented by the upper and lower limits of each box, respectively. Data points that

280 fall outside of the quartile ranges are denoted as open circles. Asterisks indicate significance at 
281 282 experiment (Table S1).

283

284

285

286

287

288

289

290

291

292

293

294

295

296

297

298

299

300

301

302

303 traps $(\mathrm{P}<0.001)$.

$\alpha=0.05$. Summary statistics and Pearson's dispersion statistic are also reported for each

Results

Experiment 1: Testing Fungal Odors. We found that the Batch \#3250 quercivorol + UHR ethanol lure attracted significantly more $\operatorname{SHB}\left(\chi^{2}=665.16\right.$; $\mathrm{df}=3 ; \mathrm{P}<0.001$; Fig 1a) than either the inoculated or uninoculated diet plug, neither of which were significantly different from our blank control trap $(\mathrm{P}=0.876$ and 0.729 , respectively).

Experiment 2: Effect of Ethanol on Quercivorol. We found that the Batch \#3250 quercivorol lure by itself attracted significantly more SHB than when the lure is paired with a UHR ethanol lure $\left(\chi^{2}=1221.03 ; \mathrm{df}=2 ; \mathrm{P}<0.001 ;\right.$ Fig $\left.1 \mathrm{~b}\right)$. Both treatments resulted in significantly higher SHB capture than blank control traps (both $\mathrm{P}<0.001)$.

Experiment 3: Analysis of Three Different Quercivorol Blends. We found that the Batch \#3250 quercivorol lure, attracted significantly more SHB than Batch \#3039 ( $\chi^{2}=134.66$; df $=2 ; \mathrm{P}<0.001)$ and Batch \#3355 ( $\mathrm{P}<0.001 ;$ Fig 2a). Batch \#3039 attracted significantly more SHB than Batch \#3355 $(\mathrm{P}<0.001)$.

Experiment 4: Analysis of Two Additional Quercivorol Blends. We found no significant difference between Batch \#3361 and Batch \#3250 $\left(\chi^{2}=25.97 ; \mathrm{df}=2 ; \mathrm{P}=0.427\right.$; Fig 2b). Both of these batches attracted significantly more SHB than Batch \#3362 $(\mathrm{P}<0.001)$.

Experiment 5: Batch \#3361 vs. P548. We found no significant difference between the number of SHB attracted to the P548 and Batch \#3361 quercivorol lures $\left(\chi^{2}=47.33 ; \mathrm{df}=2 ; \mathrm{P}=\right.$ 0.311; Fig 3). Both of these treatments attracted significantly more SHB than the blank control 

more SHB in cups containing DESS solution than either in cups with antifreeze $\left(\chi^{2}=19.53\right.$; $\mathrm{df}=$ $2 ; \mathrm{P}=0.010)$ or dry cups with Kimwipes $(\mathrm{P}<0.001 ;$ Fig $4 \mathrm{a})$. There was no significant difference between the number of SHB collected in cups with antifreeze or in dry cups $(\mathrm{P}=$ $0.359)$.

Experiment 7: Effect of Funnel Diameter and Cup Contents on SHB Capture. When dry cups were used, we found that the diameter size of the funnels had no effect on how many SHB were caught $\left(\chi^{2}=9.18 ; \mathrm{df}=2 ; \mathrm{P}=0.999 ;\right.$ Fig $\left.4 \mathrm{~b}\right)$. However, significantly more SHB were collected in cups containing DESS than in dry cups of either large or small funnel traps (both $\mathrm{P}=$ $3130.025)$.

Experiment 8: Effect of P548 Concentration. Significantly more SHB were attracted to 315 a single P548 lure than to the six-lure treatment $\left(\chi^{2}=23.14 ; \mathrm{df}=2 ; \mathrm{P}<0.001\right.$; Fig 5a). We found no significant difference in the number of SHB captured with the single lure compared to the

317 two-lure treatment $(\mathrm{P}=0.259)$. difference in the number of SHB attracted to P548 A, P548 B, and P548 C with different release rates $\left(\chi^{2}=3.06 ; \mathrm{df}=2 ;\right.$ Treatment effect $\mathrm{P}=0.315 ;$ Fig $\left.5 \mathrm{~b}\right)$ quercivorol lure as a positive control attracted a significant number of SHB weekly $\left(\chi^{2}=396.20\right.$; $\mathrm{df}=2 ; \mathrm{P}<0.001 ;$ Fig $6 \mathrm{a})$. When paired with a Batch \#3361 quercivorol lure, verbenone

324 significantly reduced the number of SHB attracted to the quercivorol lure $(\mathrm{P}<0.001)$, although it 325 still attracted significantly more SHB than the blank control trap $(\mathrm{P}<0.001)$. 
327 repellents were paired with a Batch \#3361 lure, significantly fewer SHB were collected from 328 traps with piperitone than traps with verbenone $\left(\chi^{2}=306.47 ; \mathrm{df}=2 ; \mathrm{P}<0.001 ;\right.$ Fig $\left.6 \mathrm{~b}\right)$. Both

329 repellents significantly reduced the number of SHB attracted to the Batch \#3361 quercivorol lure $330(\mathrm{P}<0.001)$.

331

\section{Discussion}

Our experiments revealed that lures containing quercivorol were attractive for the capture of PSHB and KSHB. Although quercivorol has been found in odors from sawdust-based artificial diet infested with Fusarium euwallaceae (Cooperband \& Cossé, pers. comm.), we found that SHB were not attracted in the field to diet plugs inoculated with symbiotic fungi in Experiment 1 (Fig 1a). Fungal volatiles from these lures may have been emitted at concentrations below the threshold of beetle detection under field conditions. We found that removing the UHR ethanol component greatly increased the ability of quercivorol lures to attract SHB (Fig 1b), suggesting that, unlike many other bark and ambrosia beetles that are attracted to UHR ethanol (Miller \& Rabaglia 2009; Montgomery \& Wargo 1983; Schroeder \& Lindelöw 1989), the PSHB and KSHB had an aversion to UHR ethanol, or that ethanol at that release rate had an antagonistic effect on quercivorol. We have also shown that SHB have an aversion to the repellents verbenone (Fig 6a) and piperitone (Fig 6b), which almost completely offset SHB attraction to quercivorol. We found that piperitone is a more effective deterrent for SHB than verbenone (Fig 6b), making this study the first to demonstrate the potential of piperitone for ambrosia beetle control. Studies with repellents are ongoing to determine optimal release rate, concentration, and effective distance. 
350 isomers. Both SHB seem to be most attracted to blends where cis quercivorol is the dominant

351 isomer (Fig 2), and we found no significant difference in their attraction to quercivorol lures

352 from Synergy Semiochemicals Corp. and ChemTica Internacional (Fig 3). Additionally, we

353 found that SHB do not respond differently to quercivorol lures with different release rates (Fig

$3545 b)$. We did find, however, that SHB are more responsive to lower concentrations of quercivorol

355 (Fig 5a), which attracted significantly more beetles than higher concentration treatments. These

356 findings allow for more cost-effective monitoring, since lures with lower concentrations or

357 release rates are typically less expensive to synthesize and purchase than high concentration, full 358 release rate lures.

359 Attempts to modify traps to increase SHB catch were somewhat successful. Although

360 alteration of funnels had no effect on the number of SHB being retained (Fig 4b), we found that

361 using DESS solution as a cup substrate resulted in higher numbers of SHB in trap cups than

362 when ethanol-based antifreeze was used (Fig 4a). We cannot rule out the possibility that these

363 results were caused by other factors, but this again suggests that SHB have an aversion to

364 ethanol, and also has implications for the use of DESS solution as a field preservation agent.

365 Because count data is typically skewed, the data were not transformed and are reported as

366 raw count data. However, the possible effect of outliers cannot be ignored. Removing outliers

367 changed significance of the results in one of our experiments. In Experiment 7, the difference

368 between cups with DESS and dry cups was only marginally significant after removing outliers (P

$369=0.074$ and 0.099 for large and small traps, respectively). The effect of date of collection from

370 week to week was also significant in some experiments, which may have influenced the presence

371 of outliers. There are two main explanations for this observation, the first being dosage effects 
372 that gradually diminished lure potency over the course of the experiments. This was a known and

373 uncontrollable factor in our experiments, but one that was unlikely to differentially affect our

374 results since all lures had comparable loads and release rates (except in Experiment 9, where the

375 effect of release rate was tested). The second explanation is temperature which, in addition to

376 affecting release rate, would have caused an overall increase or decrease in number of flying

377 SHB (i.e. the pool from which SHB could be collected in the field) and therefore likely would

378 have affected all treatments equally. Thus, the effect of date likely did not affect comparisons

379 between treatments.

380 Because PSHB and KSHB are members of a closely related species complex with similar

381 fungal symbionts, we assume that their responses to the lures and repellents tested are

382 comparable. Synergy Semiochemical and ChemTica quercivorol lures have both been used in

383 field experiments in La Habra Heights and Escondido, and have resulted in sufficient capture of

384 SHB in each location (unpubl. data). Both quercivorol lures are also currently used for

385 monitoring purposes across southern California (see http://eskalenlab.ucr.edu/distribution.html),

386 and have resulted in capture of both PSHB and KSHB in their respective locations. It is therefore

387 safe to say that both SHB are attracted to quercivorol; however, there may be differences in their

388 responses to other lures or repellents.

389 Due to various aspects of their ecologies, bark and ambrosia beetles are notoriously

390 difficult to control. Females spend most of their lives protected within host trees, and disperse

391 already mated with their fungal symbionts. Dispersal typically occurs over a short distance in

392 one of two ways: a flight to another suitable host, or to walk to an unoccupied area of the current

393 host tree. These factors reduce the need for sex or aggregation pheromones in SHB, and indeed

394 none have been discovered. Without the utility of artificially synthesized pheromones or ethanol 
395 lures to attract the PSHB and KSHB, the discovery of quercivorol has been a great advance to

396 our knowledge of SHB distribution and spread. Results from our field experiments have greatly

397 optimized SHB trap catch and resulted in an effective monitoring tool for these invasive pests.

398 Monitoring the PSHB and KSHB has previously required field surveys of Fusarium dieback

399 symptoms. Surveys of this kind are time-consuming and rely on accurate and complete visual

400 diagnosis by the surveyor. The development of effective lures provides for passive and less

401 subjective monitoring. Quercivorol could also potentially be used to control SHB through an

402 attract-and-kill type strategy: optimization of both lure and trap could help in decreasing overall

403 SHB population numbers in infested areas, limiting opportunities for the beetle to spread. Paired

404 with effective placement of piperitone or other repellents, this could help to protect uninfested

405 areas from SHB attack.

406

407

\section{Acknowledgements}

408 We would like to thank Synergy Semiochemicals Corp. and ChemTica Internacional for

409

supplying us with lures and keeping us informed about new syntheses to test. We would also like

410 to thank Lupe Hernandez from the Henry Avocado Corporation in Escondido, CA and Raul

411 Alvarado for allowing us to perform these field experiments in their avocado orchards. We

412 gratefully acknowledge Veronica Fernandez, Crystal May Johnston, Amanda Alcaraz, Shannen

413 Hilse, Nickolas Anthony Moreno, Barbara Baker, Augustine de Villa, and Kimberley Garcia for

414 their help with field work and data collection. We would also like to thank Paul Rugman-Jones

415 for input on statistical analyses, the Eskalen lab at UCR for providing fungal isolates, and

416 Stephanie Russell for providing DESS solution.

417 


\section{References}

422

423

424

425

426

427

428

429

430

431

432

433

434

435

436

437

438

439

440

441

442

443

444

445

446

447

448

449

450

451

452

453

454

455

456

457

458

459

460

461

Allison JD, and Redak RA. 2017. The Impact of Trap Type and Design Features on Survey and Detection of Bark and Woodboring Beetles and Their Associates: A Review and MetaAnalysis. Annu Rev Entomol 62:127-146. 10.1146/annurev-ento-010715-023516

Austin GD. 1956. Historical review of shot-hole borer investigations. Tea Quarterly 27:97-102. Boland JM. 2016. The impact of an invasive ambrosia beetle on the riparian habitats of the Tijuana River Valley, California. PeerJ 4:e2141. 10.7717/peerj.2141

Borden JH, Devlin DR, and Miller DR. 1991. Synomones of two sympatric species deter attack by the pine engraver, Ips pini (Coleoptera: Scolytidae). Canadian Journal of Forest Research 22:381-387.

Burbano EG, Wright MG, Gillette NE, Mori S, Dudley N, Jones T, and Kaufmann M. 2012. Efficacy of traps, lures, and repellents for Xylosandrus compactus (Coleoptera: Curculionidae) and other ambrosia beetles on Coffea arabica plantations and Acacia koa nurseries in Hawaii. Environ Entomol 41:133-140. 10.1603/EN11112

Byers JA. 1989. Chemical ecology of bark beetles. Experientia 45:271-283.

Byers JA, Maoz Y, and Levi-Zada A. 2017. Attraction of the Euwallacea sp. near fornicatus (Coleoptera: Curculionidae) to Quercivorol and to Infestations in Avocado. J Econ Entomol. 10.1093/jee/tox 151

California Avocado Commission. 2017. California Avocado Commission 2016 Annual Report. Irvine, CA. p 1-54.

Carrillo D, Narvaez T, Cosse AA, Stouthamer R, and Cooperband M. 2015. Attraction of Euwallacea nr. fornicatus (Coleoptera: Curculionidae: Scolytinae) to lures containing quercivorol. Florida Entomologist 98:780-782.

Cooperband MF, Stouthamer R, Carrillo D, Eskalen A, Thibault T, Cossé AA, Castrillo LA, Vandenberg JD, and Rugman-Jones PF. 2016. Biology of two members of the Euwallacea fornicatus species complex (Coleoptera: Curculionidae: Scolytinae), recently invasive in the U.S.A., reared on an ambrosia beetle artificial diet. Agricultural and Forest Entomology 18:223-237. 10.1111/afe.12155

Eichhoff W. 1868. Neue amerikanische Borkenkafer-Gattungen und Arten II. Berliner Entomologische Zeitschrift 12:145-152.

Erbilgin N, Powell JS, and Raffa KF. 2003. Effect of varying monoterpene concentrations on the response of Ips pini (Coleoptera: Scolytidae) to its aggregation pheromone: implications for pest management and ecology of bark beetles. Agricultural and Forest Entomology 5:269-274.

Eskalen A, Gonzalez A, Wang DH, Twizeyimana M, Mayorquin JS, and Lynch SC. 2012. First Report of a Fusarium sp. and Its Vector Tea Shot Hole Borer (Euwallacea fornicatus) Causing Fusarium Dieback on Avocado in California. Plant Disease 96:1070-1070. 10.1094/PDIS-03-12-0276-PDN

Eskalen A, Stouthamer R, Lynch SC, Rugman-Jones PF, Twizeyimana M, Gonzalez A, and Thibault T. 2013. Host Range of Fusarium Dieback and Its Ambrosia Beetle (Coleoptera: Scolytinae) Vector in Southern California. Plant Disease 97:938-951. 
462 Fettig CJ, McKelvey SR, Dabney CP, Borys RR, and Huber DPW. 2009. Response of

463

464

465

466

467

468

469

470

471

472

473

474

475

476

477

478

479

480

481

482

483

484

485

486

487

488

489

490

491

492

493

494

495

496

497

498

499

500

501

502

503

504

505

506

Dendroctonus brevicomis to different release rates of nonhost angiosperm volatiles and verbenone in trapping and tree protection studies. Journal of Applied Entomology 133:143-154. 10.1111/j.1439-0418.2008.01317.x

Freeman S, Protasov A, Sharon M, Mohotti K, Eliyahu M, Okon-Levy N, Maymon M, and Mendel Z. 2013a. Obligate feed requirement of Fusarium sp. nov., an avocado wilting agent, by the ambrosia beetle Euwallacea aff. fornicata. Symbiosis 58:245-251. 10.1007/s 13199-013-0222-6

Freeman S, Sharon M, Dori-Bachash M, Maymon M, Belausov E, Maoz Y, Margalit O, Protasov A, and Mendel Z. 2015. Symbiotic association of three fungal species throughout the life cycle of the ambrosia beetle Euwallacea nr. fornicatus. Symbiosis 68:115-128.

10.1007/s 13199-015-0356-9

Freeman S, Sharon M, Maymon M, Mendel Z, Protasov A, Aoki T, Eskalen A, and O'Donnell K. 2013b. Fusarium euwallaceae sp. nov.--a symbiotic fungus of Euwallacea sp., an invasive ambrosia beetle in Israel and California. Mycologia 105:1595-1606. 10.3852/13066

García-Avila CDJ, Trujillo-Arriaga FJ, López-Buenfil JA, González-Gómez R, Carrillo D, Cruz LF, Ruiz-Galván I, Quezada-Salinas A, and Acevedo-Reyes N. 2016. First Report of Euwallacea nr. fornicatus (Coleoptera: Curculionidae) in Mexico. Florida Entomologist 99:555-556. 10.1653/024.099.0335

Hughes MA, Martini X, Kuhns E, Colee J, Mafra-Neto A, Stelinski LL, and Smith JA. 2017. Evaluation of repellents for the redbay ambrosia beetle, Xyleborus glabratus, vector of the laurel wilt pathogen. Journal of Applied Entomology:1-12. 10.1111/jen.12387

Hulcr J, Mann R, and Stelinski LL. 2011. The scent of a partner: ambrosia beetles are attracted to volatiles from their fungal symbionts. $J$ Chem Ecol 37:1374-1377. 10.1007/s10886-0110046-x

Jaramillo J, Torto B, Mwenda D, Troeger A, Borgemeister C, Poehling HM, and Francke W. 2013. Coffee berry borer joins bark beetles in coffee klatch. PLoS One 8:e74277. 10.1371/journal.pone.0074277

Jordal BH. 2000. Evolutionary radiation of an inbreeding haplodiploid beetle lineage (Curculionidae, Scolytinae). Biological Journal of the Linnean Society 71:483-499.

Kashiwagi T, Nakashima T, Tebayashi S, and Kim C. 2006. Determination of the absolute configuration of quercivorol, (1S,4R)-p-Menth-2-en-1-ol, an aggregation pheromone of the ambrosia beetle Platypus quercivorus (Coleoptera: Platypodidae). Biosci Biotechnol Biochem 70:2544-2546. 10.1271/bbb.60211]

Kasson MT, O'Donnell K, Rooney AP, Sink S, Ploetz RC, Ploetz JN, Konkol JL, Carrillo D, Freeman S, Mendel Z, Smith JA, Black AW, Hulcr J, Bateman C, Stefkova K, Campbell PR, Geering AD, Dann EK, Eskalen A, Mohotti K, Short DP, Aoki T, Fenstermacher KA, Davis DD, and Geiser DM. 2013. An inordinate fondness for Fusarium: phylogenetic diversity of fusaria cultivated by ambrosia beetles in the genus Euwallacea on avocado and other plant hosts. Fungal Genet Biol 56:147-157. 10.1016/j.fgb.2013.04.004

Kirkendall LR. 1993. Ecology and evolution of biased sex ratios in bark and ambrosia beetles. In: Wrensch DL, and Ebbert MA, eds. Evolution and Diversity of Sex Ratio in Insects and Mites. New York: Chapman \& Hall, 235-345.

PeerJ reviewing PDF | (2017:05:18127:1:0:REVIEW 11 Jul 2017) 
507 Kirkendall LR, and Jordal BH. 2006. The bark and ambrosia beetles (Curculionidae, Scolytinae)

508

509

510

511

512

513

514

515

516

517

518

519

520

521

522

523

524

525

526

527

528

529

530

531

532

533

534

535

536

537

538

539

540

541

542

543

544

545

546

547

548

549

550

551

552

of Cocos Island, Costa Rica and the role of mating systems in island zoogeography. Biological Journal of the Linnean Society 89:729-743. Doi 10.1111/J.10958312.2006.00698.X

Kovanci OB, Schal C, Walgenbach JF, and Kennedy GG. 2006. Effects of pheromone loading, dispenser age, and trap height on pheromone trap catches of the oriental fruit moth in apple orchards. Phytoparasitica 34:252-260.

Kuhns EH, Tribuiani Y, Martini X, Meyer WL, Pena J, Hulcr J, and Stelinski LL. 2014. Volatiles from the symbiotic fungus Raffaelea lauricola are synergistic with Manuka lures for increased capture of the Redbay ambrosia beetle Xyleborus glabratus. Agricultural and Forest Entomology 16:87-94. 10.1111/afe.12037

Lenth RV. 2016. Least-Squares Means: The R Package lsmeans. Journal of Statistical Software 69:1-33. doi:10.18637/jss.v069.i01

Lynch SC, Twizeyimana M, Mayorquin JS, Wang DH, Na F, Kayim M, Kasson MT, Thu PQ, Bateman C, Rugman-Jones P, Hulcr J, Stouthamer R, and Eskalen A. 2016. Identification, pathogenicity and abundance of Paracremonium pembeum sp. nov. and Graphium euwallaceae sp. nov.--two newly discovered mycangial associates of the polyphagous shot hole borer (Euwallacea sp.) in California. Mycologia 108:313-329. 10.3852/15-063

Mendel Z, Protasov A, Sharon M, Zveibil A, Yehuda SB, O’Donnell K, Rabaglia R, Wysoki M, and Freeman S. 2012. An Asian ambrosia beetle Euwallacea fornicatus and its novel symbiotic fungus Fusarium sp. pose a serious threat to the Israeli avocado industry. Phytoparasitica 40:235-238. 10.1007/s12600-012-0223-7

Miller DR, and Rabaglia RJ. 2009. Ethanol and (-)-alpha-Pinene: attractant kairomones for bark and ambrosia beetles in the southeastern US. J Chem Ecol 35:435-448. 10.1007/s 10886009-9613-9

Montgomery ME, and Wargo PM. 1983. Ethanol and other host-derived volatiles as attractants to beetles that bore into hardwoods. J Chem Ecol 9:181-190.

Normark BB, Jordal BH, and Farrell BD. 1999. Origin of a haplodiploid beetle lineage. Proc $R$ Soc Lond 266:2253-2259.

O'Donnell K, Sink S, Libeskind-Hadas R, Hulcr J, Kasson MT, Ploetz RC, Konkol JL, Ploetz JN, Carrillo D, Campbell A, Duncan RE, Liyanage PN, Eskalen A, Na F, Geiser DM, Bateman C, Freeman S, Mendel Z, Sharon M, Aoki T, Cossé AA, and Rooney AP. 2015. Discordant phylogenies suggest repeated host shifts in the Fusarium-Euwallacea ambrosia beetle mutualism. Fungal Genet Biol. 10.1016/j.fgb.2014.10.014

O'Donnell K, Sutton DA, Fothergill A, McCarthy D, Rinaldi MG, Brandt ME, Zhang N, and Geiser DM. 2008. Molecular phylogenetic diversity, multilocus haplotype nomenclature, and in vitro antifungal resistance within the Fusarium solani species complex. J Clin Microbiol 46:2477-2490. 10.1128/JCM.02371-07

Peer K, and Taborsky M. 2004. Female ambrosia beetles adjust their offspring sex ratio according to outbreeding opportunities for their sons. Journal of Evolutionary Biology 17:257-264. 10.1111/j.1420-9101.2003.00687.x

R Core Team. 2015. R: A language and environment for statistical computing. Vienna, Austria: R Foundation for Statistical Computing.

Rabaglia RJ, Dole SA, and Cognato AI. 2006. Review of American Xyleborina (Coleoptera: Curculionidae: Scolytinae) Occurring North of Mexico, with an Illustrated Key. Annals 
553

554

555

556

557

558

559

560

561

562

563

564

565

566

567

568

569

570

571

572

573

574

575

576

577

578

579

580

581

582

of the Entomological Society of America 99:1034-1056. 10.1603/00138746(2006)99[1034:roaxcc]2.0.co;2

Raffa KF, Phillips TW, and Salom SM. 1993. Strategies and Mechanisms of Host Colonization by Bark Beetles. In: Schowalter TD, and Filip GM, eds. Beetle-Pathogen Interactions in Conifer Forests: Academic Press, 252.

Schroeder LM, and Lindelöw Å. 1989. Attraction of scolytids and associated beetles by different absolute amounts and proportions of $\alpha$-pinene and ethanol. J Chem Ecol 15:807-817.

Stouthamer R, Rugman-Jones P, Thu PQ, Eskalen A, Thibault T, Hulcr J, Wang L-J, Jordal BH, Chen C-Y, Cooperband M, Lin C-S, Kamata N, Lu S-S, Masuya H, Mendel Z, Rabaglia R, Sanguansub S, Shih H-H, Sittichaya W, and Zong S. 2017. Tracing the origin of a cryptic invader: phylogeography of the Euwallacea fornicatus (Coleoptera: Curculionidae: Scolytinae) species complex. Agricultural and Forest Entomology. 10.1111/afe. 12215

Tokoro M, Kobayashi M, Saito S, Kinuura H, Nakashima T, Shoda-Kagaya E, Kashiwagi T, Tebayashi S, Kim C, and Mori K. 2007. Novel aggregation pheromone, (1S,4R)-pmenth-2-en-1-ol, of the ambrosia beetle, Platypus quercivorus (Coleoptera: Platypodidae). Bulletin of FFPRI 6:49-57.

University of California. 2015. Pest Infestation in UCI Campus Trees. In: University of California, Irvine, editor: University of California Cooperative Extension.

Venables WN, and Ripley BD. 2002. Modern Applied Statistics with S. New York, NY: Springer.

Walgama RS, and Pallemulla RMDT. 2005. The distribution of shot-hole borer, Xyleborus fornicatus Eichh. (Coleoptera: Scolytidae), across tea-growing areas in Sri Lanka: A reassessment. SL J Tea Sci 70:105-120.

Witzgall P, Stelinski L, Gut L, and Thomson D. 2008. Codling moth management and chemical ecology. Аnnu Rev Entomol 53:503-522. 10.1146/annurev.ento.53.103106.093323

Yoder M, Tandingan De Ley I, King IW, Mundo-Ocampo M, Mann J, Blaxter M, Poiras L, and De Ley P. 2006. DESS: a versatile solution for preserving morphology and extractable DNA of nematodes. Nematology 8:367-376. 


\section{Figure 1 (on next page)}

Figure 1: Effect of fungal odors and ethanol on SHB attraction.

Number of shot hole borers collected from traps for each treatment. a) Experiment 1 The paired Batch \#3250 quercivorol + UHR ethanol lure attracted significantly more SHB than either the inoculated or uninoculated diet tubes $(P<0.001)$, neither of which was significantly different from the blank control trap

$(P=0.876$ and 0.729 , respectively). b) Experiment 2 The Batch \#3250 quercivorol lure by itself attracted significantly more SHB than when paired with a UHR ethanol lure $(P<0.001)$. Both treatments attracted significantly more SHB than the blank control trap $(P<0.001)$. 
a)

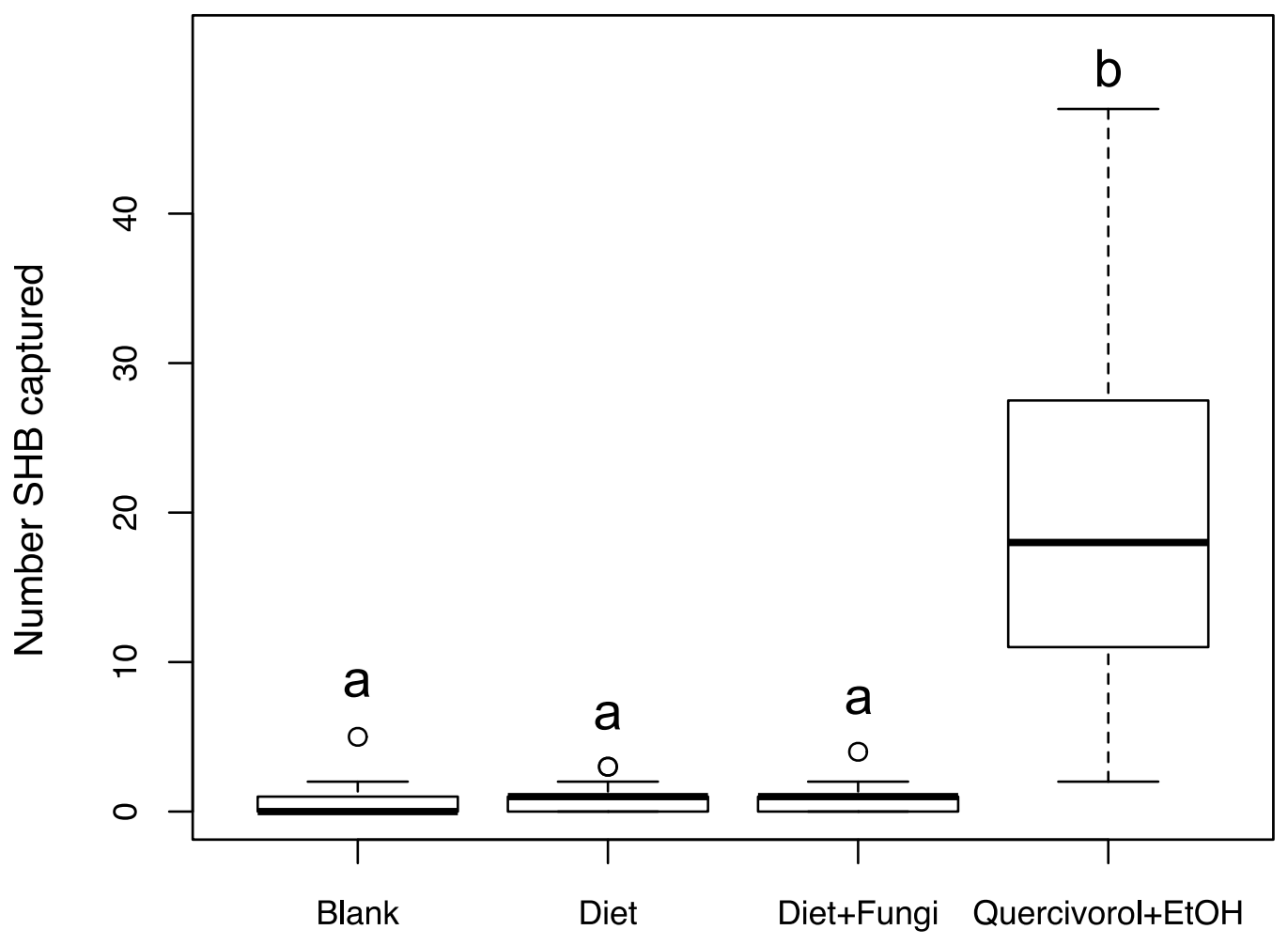

Treatment b)

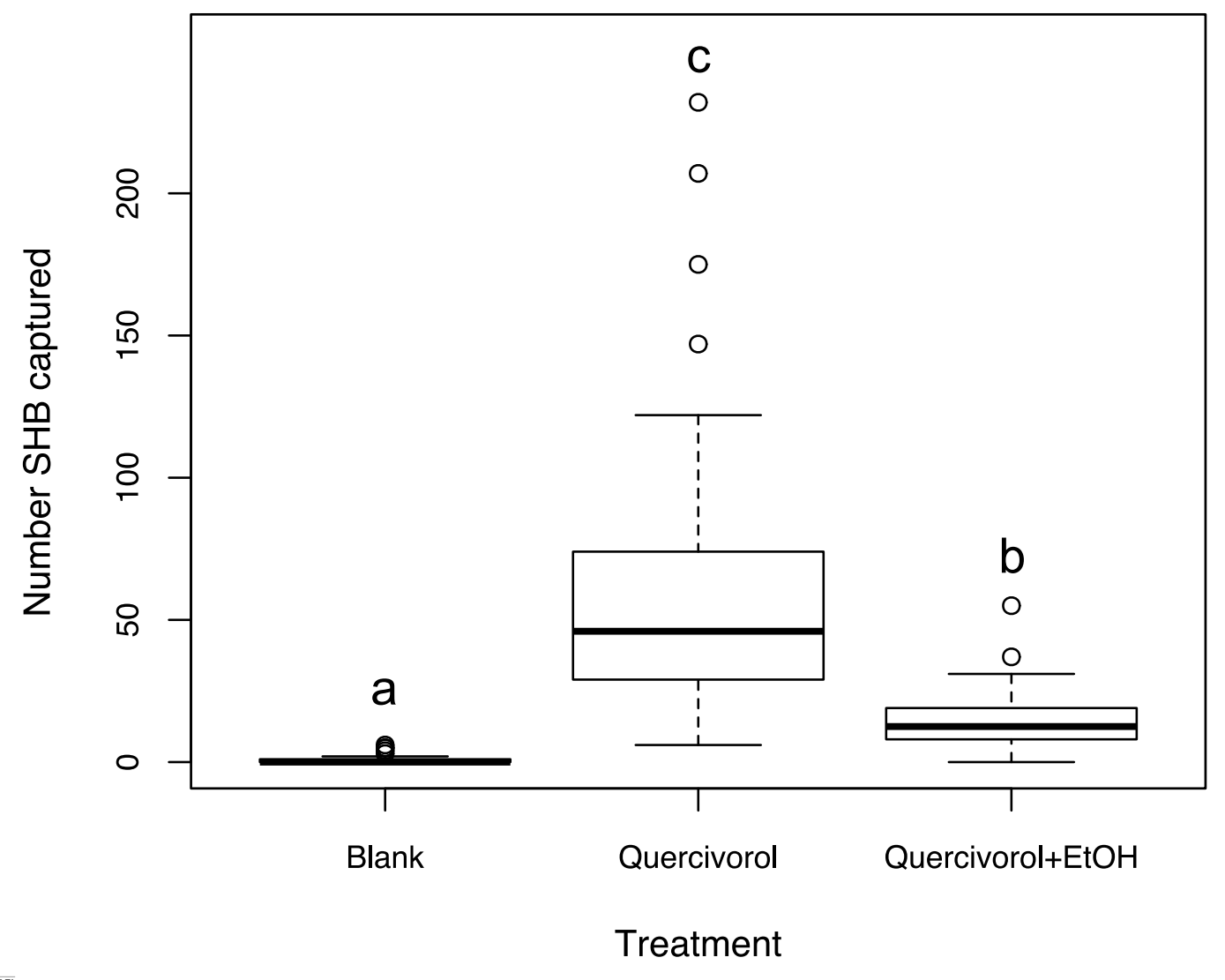




\section{Figure 2 (on next page)}

Figure 2: Testing different quercivorol formulations.

Number of shot hole borers collected from traps for each treatment. a) Experiment 3 Significantly more SHB were attracted to Batch \#3250 than to either Batch \#3039 ( $<<$ 0.001 ) and Batch \#3355 ( $P<0.001)$. Batch \#3039 attracted significantly more SHB than Batch \#3355 ( $P<0.001)$. b) Experiment 4 There was no significant difference in number of SHB attracted to Batch \#3250 and Batch \#3361 ( $P=0.427)$, both of which attracted significantly more SHB than Batch \#3362 $(P<0.001)$. 

a)
PeerJ
Manuscript to be reviewed
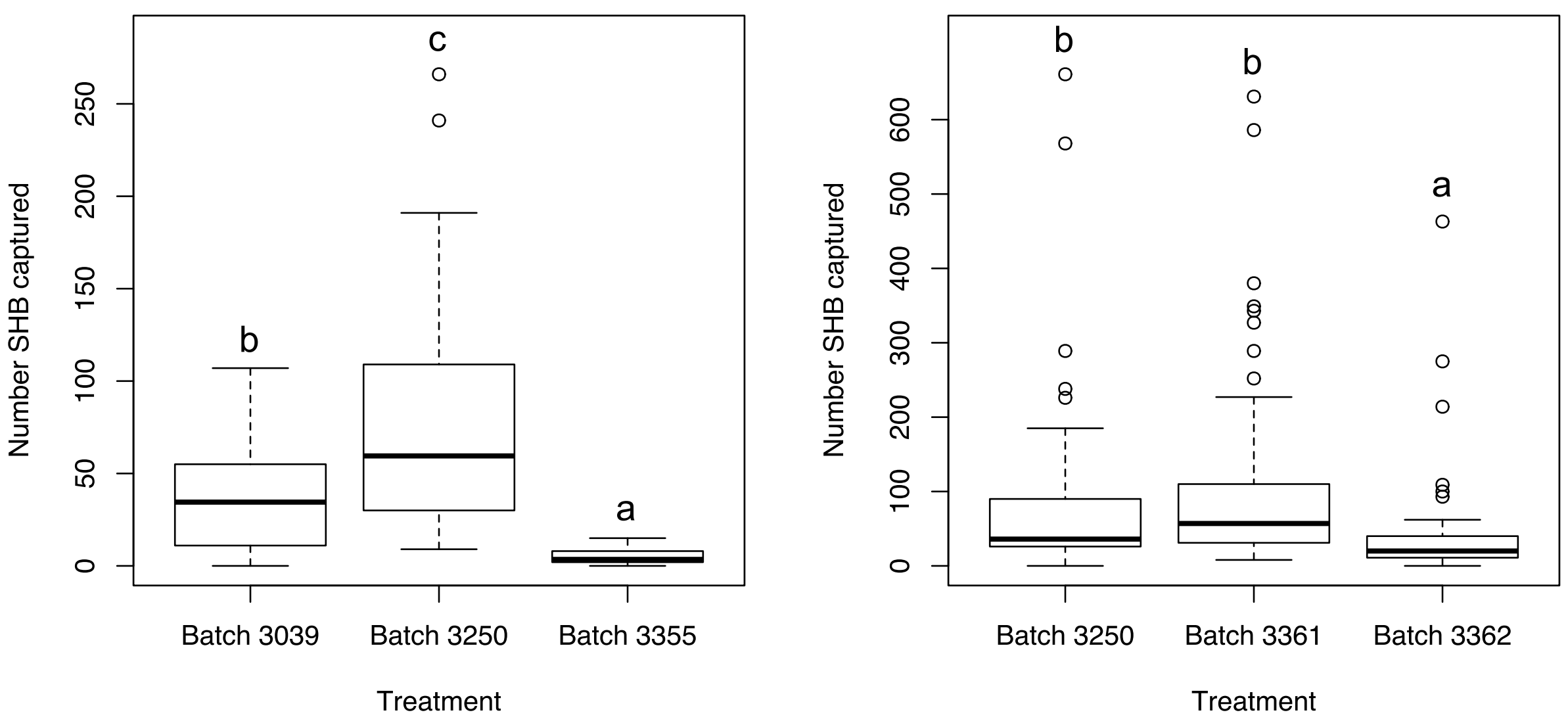


\section{Figure 3 (on next page)}

Figure 3: Testing two quercivorols.

Number of shot hole borers collected from traps for each treatment over a twoweek period. Experiment 5 There was no significant difference in the number of SHB collected from traps baited with Batch \#3361 (Synergy Semiochemicals) or with P548 (ChemTica Internacional; $\mathrm{P}=0.311$ ). 


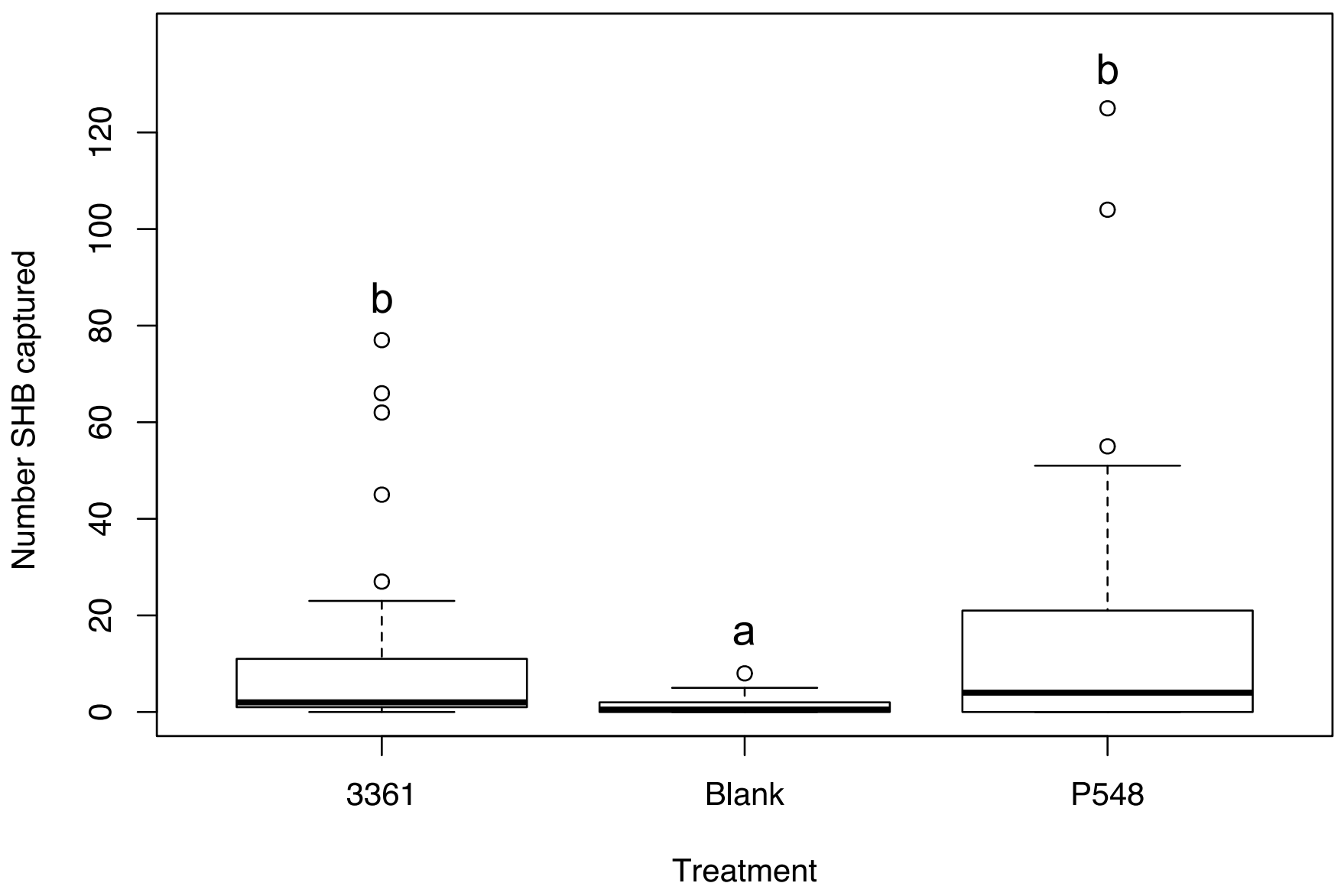




\section{Figure 4 (on next page)}

Figure 4: Effect of trap alterations.

Number of shot hole borers collected from traps for each treatment. a) Experiment 6 Significantly more SHB were collected from trap cups containing DESS solution than either cups with antifreeze $(P=0.010)$ or dry cups $(P<0.001)$. b) Experiment 7 Size of funnel diameter had no effect on number of SHB captured $(P=0.999)$. Significantly more SHB were collected from cups contained DESS solution than dry cups of either large or small funnel traps (both $\mathrm{P}=0.025$ ). 
a)

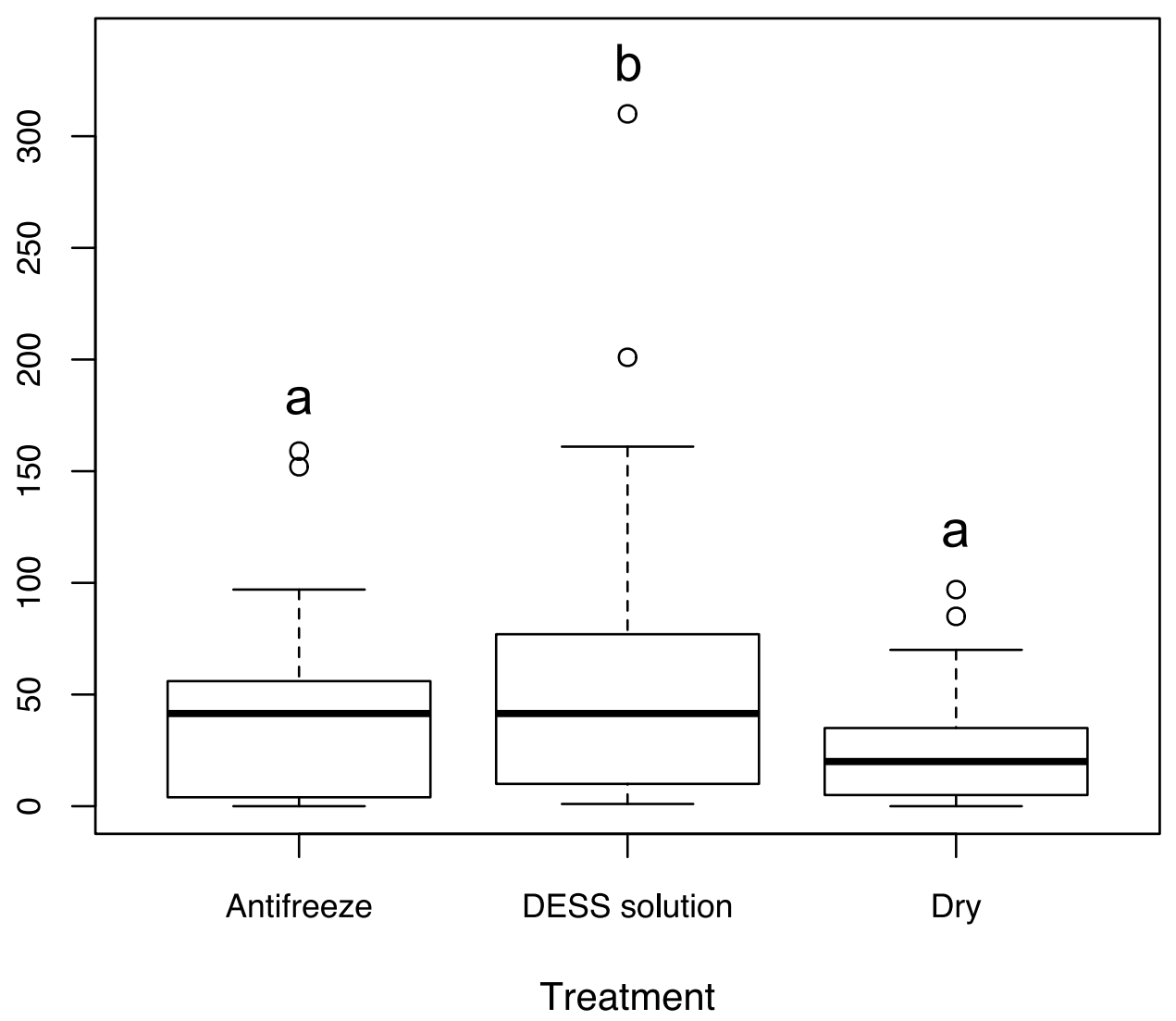

Manuscript to be reviewed

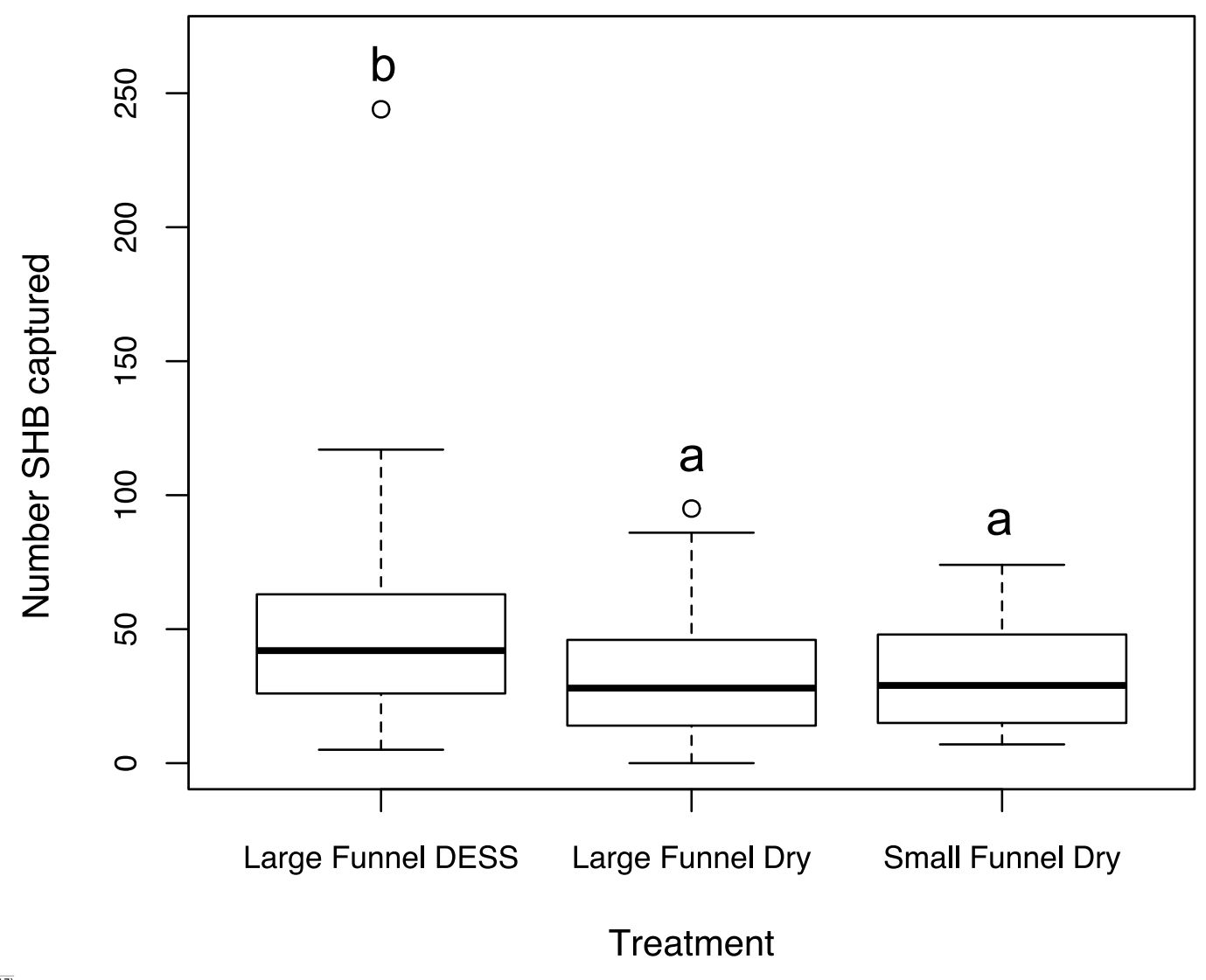




\section{Figure $\mathbf{5}$ (on next page)}

Figure 5: Effect of lure concentration and release rate.

Number of shot hole borers collected from traps for each treatment. a) Experiment

8 Significantly more SHB were attracted to the one- and two-lure treatments than the six-lure treatment $(P<0.001)$. There was no significant difference between the one- and two-lure treatments $(P=0.259)$. b) Experiment 9 Release rate had no significant effect on number of SHB captured (Treatment $P=0.315$ ). 
Figure 6 (on next page)

Figure 6: Effect of two repellents, verbenone and piperitone.

Number of shot hole borers collected from traps for each treatment. a) Experiment

10 Verbenone significantly reduced the number of SHB attracted to quercivorol $(P<0.001)$, although this paired lure still attracted more SHB than the blank control trap $(P<0.001)$. b) Experiment 11 When both were paired with quercivorol, significantly fewer SHB were collected from traps with piperitone than traps with verbenone $(P<0.001)$. Both repellents significantly reduced SHB attraction compared to the quercivorol lure alone $(P<0.001)$. 
a)

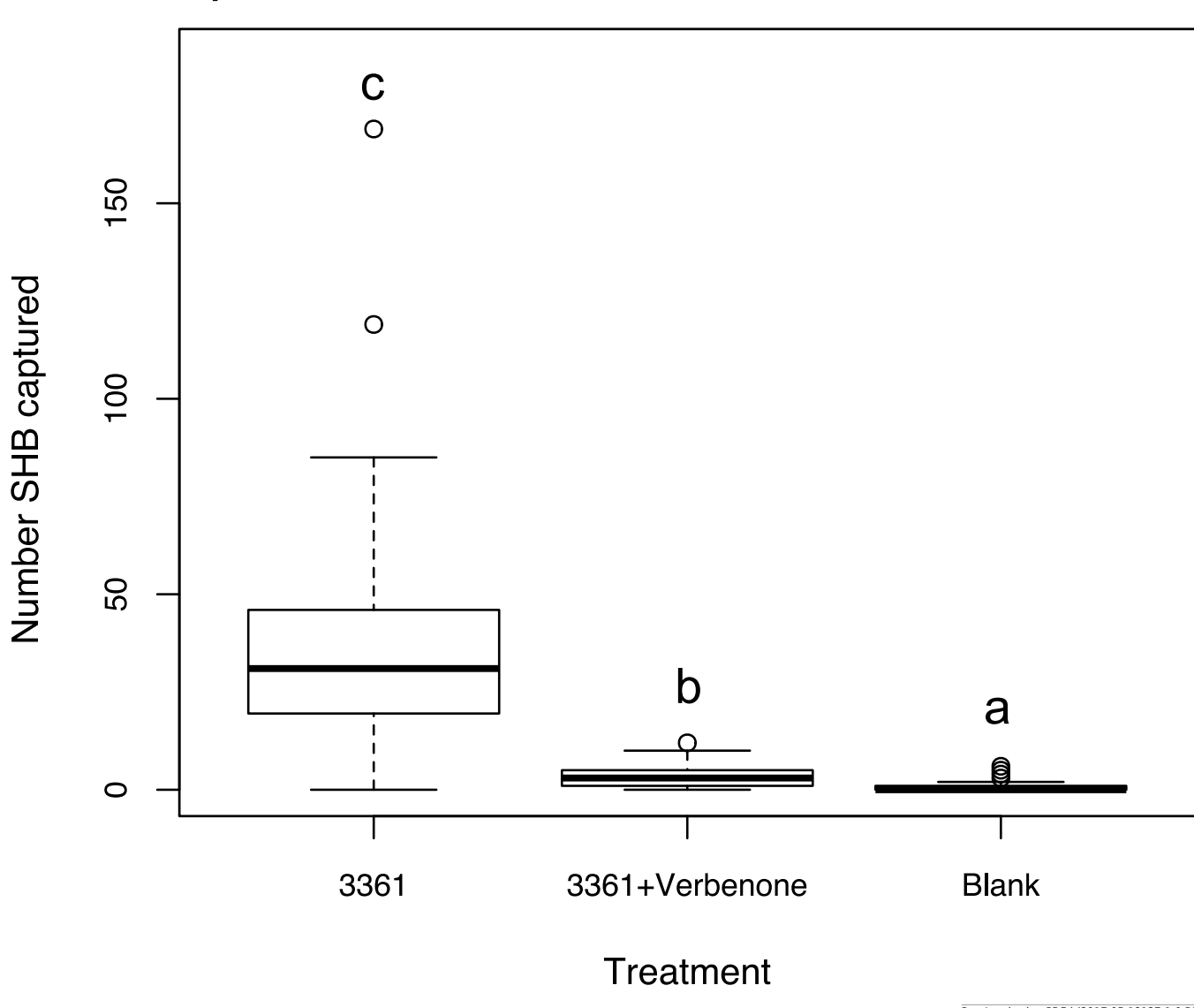

Manuscript to be reviewed

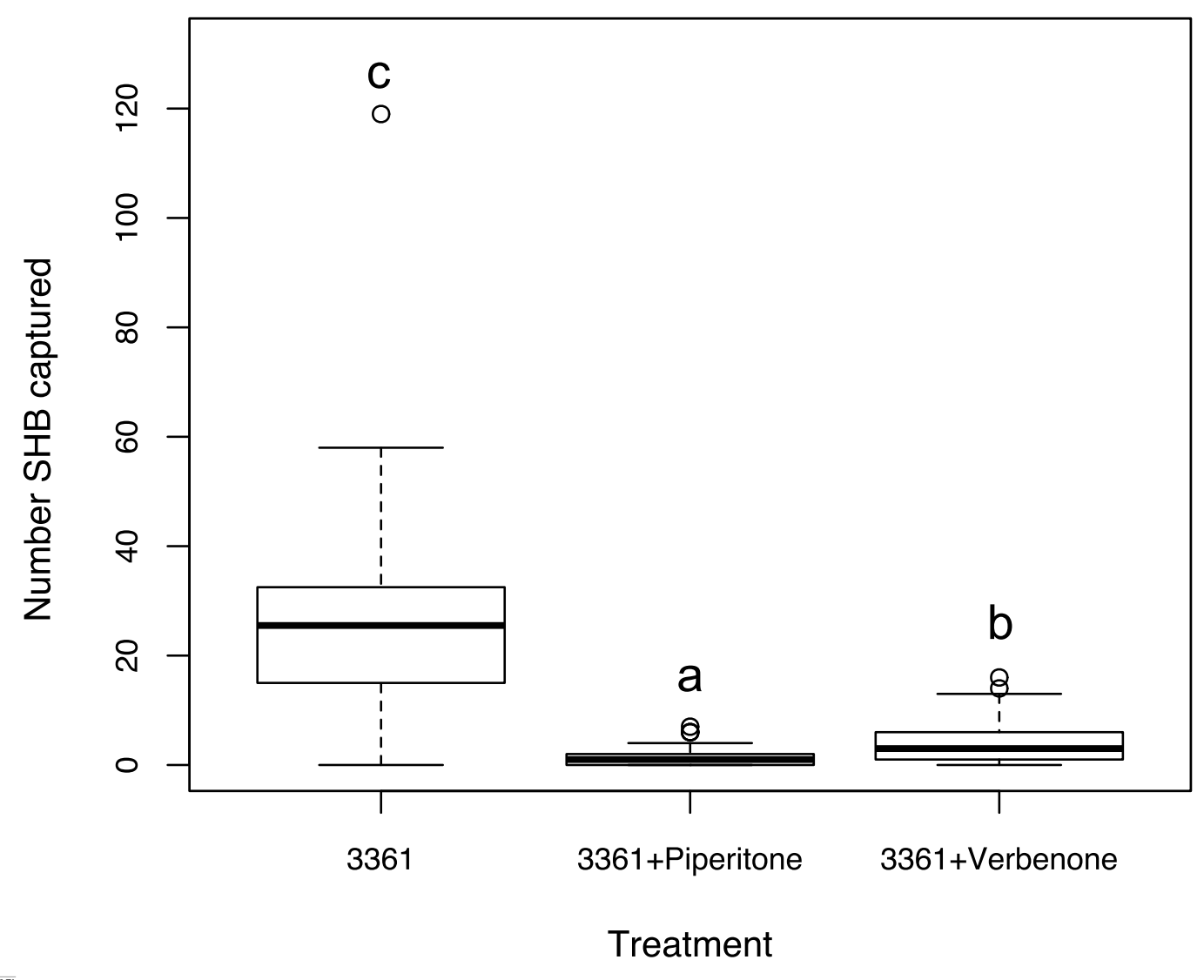

